\title{
Reputation and talent mobility in the Asia Pacific
}

\author{
William S. Harvey and Dimitria Groutsis
}

\section{Keywords}

Talent; Skilled Mobility; Migration; Reputation; Asia Pacific

\section{Abstract}

This paper argues that different forms of reputation are important for the attraction and retention of talent. Drawing-upon the skilled migration literature as well as examples from national governments, supranational organisations and the mass media, we provide a typology that highlights the intersections between reputation and talent mobility. We provide three important contributions. First, we illustrate that reputation plays a central role in the global competition for talent. Second, we highlight that the reputations of countries affect the attraction and retention of top workers. Third, we show that global talent is not only influenced by country reputation but they also produce reputations which is manifest at the individual level through the inflow and outflow of talent. These contributions shed new theoretical and practical insights on the importance and impact of reputation for talent mobility.

\section{Introduction}

While there is an important and expanding literature on the significance of talent for global labour markets (Florida, 2005; Saxenian, 2006; Tarique and Schuler, 2010), there has been relatively little research on the role of reputation as a driver for the movement of skilled workers, despite the notable emphasis in the business press (AFR, 2012). This is a major oversight because host and home countries arguably rely on positive reputations in order to encourage talent to move and/or stay. Reputation represents the collective assessment of individual perceptions of particular stakeholder groups towards an entity (e.g. country or organisation) compared to another reference group (e.g. other countries or organisations) (Fombrun, 1996, 2012; Walker, 2010). To date, the literature on reputation has predominantly focused on organisations, but we argue that reputation also plays an important role for countries in their ability to attract and retain talented mobile workers. As such the main focus of the paper is on country reputation in attracting or repelling talent. In addition, the positive or negative experiences of talented workers migrating and integrating into host countries directly shapes their perceptions as well as the perceptions of future talented workers (Beaverstock, 2002; Author, 2011a; Iredale, 2001; Author, 2012a, Author 2012b). As such we argue that individuals are also important purveyors of reputation.

We find that reputation plays a significant role in driving skilled workers to move to particular places or may also inhibit their migration. This has important theoretical implications because our understanding of reputation in the context of talent mobility is limited. This has significant practical implications because governments need to do more to build and manage their reputations if they wish to attract and retain global talent and/or skilled workers (we use these terms interchangeably throughout). The paper provides three major contributions. First, we highlight through a typology that reputation plays a central role in the attraction and retention of talent in the Asia Pacific. Second, we show that different forms of reputation affect the attraction and retention of 
top workers. Third, we illustrate that global talent is not only influenced by different types of reputations, but also actively produces reputations through their direct experiences and perceptions.

The paper provides a typology that highlights how the reputation of host and home countries can lead to positive and negative outcomes in terms of the mobility of talent. This paper also provides a critical overview of how home and host countries are importing global talent and exporting domestic talent as part of their competitive strategies, drawing on the Asia Pacific region as a case in point. Accordingly, the paper begins by introducing the literature on talent and reputation, before focusing on the context of the Asia Pacific. We deliberately draw on a breadth of examples from the academic literature, national governments, supranational organisations and the mass media for two main reasons. First, to demonstrate the multitude of different approaches that national governments are adopting to attract and retain talent in the Asia Pacific (Chambers et al., 1998; Author, 2013), rather than focusing on a small number of selective cases, which would not capture the variety of examples from across the region. Second, through drawing upon a cross-section of sources, this strengthens our theoretical and practical insights because these sources on reputation and talent mobility have tended to be analysed in isolation from each other rather than in unison. This paper presents an opportunity to engage with a wider body of empirical evidence. The above discussion leads us to ask the following central research question:

To what extent and in what ways is reputation important for influencing the mobility of talent in the Asia Pacific?

From this central question we also address how home and host country reputations pull or push skilled individuals, and what are the positive and negative implications on home and host country brain gain, brain drain, brain circulation and brain waste.

\section{Talent and reputation in the Asia Pacific: Defining concepts and identifying intersections}

There is a wealth of academic research on talent management in various regional contexts (Collings et al., 2009; Cooke, 2011, 2012; Jones et al., 2012; McDonnell et al., 2011, 2012). The Asia Pacific is an under-researched region in the context of talent management, but highly diverse with varying levels of economic development. Although the aim of this paper is not to provide an exhaustive overview of the initiatives of different countries, we provide an extensive and cross-section of examples rather than a few select examples to highlight the sheer diversity and complexity of global and domestic talent issues across the region. Through this illustration we show the intersections between talent mobility and reputation.

The Asia Pacific is an important region of analysis in the context of the import of global talent and the export of domestic talent because countries within this region have experienced brain gain, brain drain, brain exchange, brain circulation and brain waste. These guiding concepts are defined as follows. A brain gain is when a country experiences a net gain of human capital (Stark et al., 1997), a brain drain is when a country experiences a net loss of human capital (Grubel and Scott, 1966), a brain exchange is when there is no net gain or loss of human capital but still movement of people (Straubhaar, 2000), brain circulation is when a migrant returns to and/or invests in the host and/or home country (Saxenian, 2005), and brain waste is when people are not working in areas commensurate with their training and skills (Nakamuro and 
Ogawa, 2010). Reputation also arguably impacts the mobility of talent and is used here following Fombrun's (1996) definition, namely that it is based on the aggregation of the perceptual judgments of stakeholders in relation to its competitors, and following Walker (2010), namely that reputation can be positive or negative, and is generally stable and enduring. While Fombrun (1996) and Walker (2010) focused on reputation in the context of organisations, we extend the use of reputation to the context of countries while also making reference to the individual as a purveyor of reputation. This is important because the reputations of countries and individuals are also arguably significant when considering talent mobility in the Asia Pacific.

Over the last two to three decades, the attraction of global talent has emerged as a key policy concern for many countries in order to fill skill shortages in the labour market as well as to bolster economic competitiveness. National governments have come to recognise the enormous value of imported human capital resources in all areas of their economy (Tung, 2008; Al Ariss and Syed, 2011; Wright, 2013). Building a positive country reputation for attracting talented workers from abroad is considered not only effective for national competitiveness, but also for encouraging additional skilled workers to move via the process of chain migration (MacDonald and MacDonald, 1964). For instance, in Australia such initiatives include the well-known 457 visa category, which allows businesses to sponsor and nominate foreign workers if they are unable to find a suitably skilled Australian citizen or permanent resident to fill a position listed in the 'Consolidated Sponsored Occupations List' (DIAC, 2012). This example demonstrates how governments in the Asia Pacific are making active attempts to build their reputation as a country which is open to attracting global talent across a range of skilled professions. Research from the private sector suggests that a country's reputation is an important pull factor in attracting talent. Employer Branding Today (2011), for example, finds that countries with negative reputations will struggle to attract talented workers.

Having said this, the reputations of organisations can sometimes be at odds with country reputations. The positive customer perceptions of Samsung and LG products, for instance, has been critical for increasing global awareness of both firms in the labour market, but Graves (2010) argues that despite the success of these firms in attracting local talent, they have been less successful at attracting global talent because many people do not recognise that they are South Korean firms, often confusing them as Japanese firms. This highlights the importance of and interconnection between country and organisational reputation for attracting different types of talent. More recently, Samsung has attempted to source and attract foreign-born and particularly Indian software developers to the company in South Korea in order to remain competitive in mobile software development (Kim and Lee, 2012). Here, reputation plays a critical role for different actors: on the one hand the corporate reputation of Samsung as a 'celebrity firm' (Wade et al., 2006) has been central to attracting Indian software developers to the country, but on the other hand the country reputation of India as an educator and developer of excellent software engineers has also been important for Samsung in identifying where it will source its foreign talent. In summary, different forms of reputation are important in determining what talent is targeted and why, as well as significant in determining who will move and where they will move to. 


\section{Typology of reputation and talent mobility}

Having identified the importance of reputation for talent mobility within the Asia Pacific, the remainder of the paper provides a typology of the region from the perspective of host and home countries (see Figure 1 for an illustrative summary). We provide a range of examples from across the Asia Pacific to highlight firstly the diversity of mobilities across the region and secondly to show how talent is influenced by and also produces reputation. It will be shown that there is overlap between a country's reputation in attracting global talent (brain gain), losing talent (brain drain), underutilising talent (brain waste) as well as diaspora talent who are investing (brain circulation). While so, we will examine each of these aspects of talent mobility and the influence of reputation in isolation so as to construct our typology.

\section{Positive reputations}

This section focuses on host and home countries that have benefited from talent staying (brain gain) or returning to and/or investing in the country (brain circulation) as a result of their positive reputations. We begin by focusing on brain gain from the host country and home country perspective before focusing on brain circulation from the host country and home country perspective.

\section{Host and Home country: brain gain}

A number of countries in the Asia Pacific have benefited from the inflow of foreign talent. Singapore, for example, has a policy and a reputation for attracting foreign workers who hold specialised skills. Singapore's Prime Minister Lee Hsien Loong, was quoted as saying: "we must attract people who can make a contribution to Singapore to come to Singapore" and "we try to make it such that if you come (to Singapore) and make a contribution, you can do well and fulfill your potential" (The Temasek Times, 2012). While research suggests that the strong emphasis on attracting global talent in Singapore sees foreign workers receiving better incentives than the local population (Koh, 2003), the Singaporean government is also encouraging and investing in its brightest and best Singaporeans to return to Singapore after their education and training abroad. To illustrate, there are an estimated 200,000 Singaporeans who are studying and working overseas and Victor Tay, the Chief Operating Officer of the Singapore Business Federation, has recognised these highly skilled workers as vital for the future success of the Singaporean economy (Hydrogen, 2013). Ho (2011) argues that diaspora strategies aimed at professional and business class emigrants have become increasingly common as they seek a prime position in the competitive knowledge-based economy. The government has also established offices in economic hubs such as Silicon Valley in order to encourage scientists, engineers and entrepreneurs to invest in Singapore (Ong, 2007). Despite the economic benefits of a government policy that emphasises the attraction of global talent, there have also been social repercussions with the local population concerned that this is putting too much strain on infrastructure, housing and transport costs and the availability of jobs (Adam, 2013). The Singaporean case highlights that although the region has been successful at attracting global talent, it also simultaneously loses its talent (at least temporarily) to other popular global locations such as the US, the UK and Australia. This highlights how countries are not necessarily confined to a single category such as a brain gain, but often falling into multiple categories such as a brain gain and a brain drain, depending on the economic sector and timeframe. 
Hong Kong is another example of a place which has attracted global talent. Like Singapore, Hong Kong is considered a global city and a major financial centre and as such it too has had the ability to attract skilled workers, particularly within the large financial services sector because it is one of the most reputable global financial centres and highly connected to other major financial centres such as London and New York (Findlay et al., 1996; Beaverstock, 2002; Derudder et al., 2010). Despite proving to be a popular destination for mobile talent who are looking to gain global experience and professional opportunities, its reputation for quality of life, which is an important drawcard for many skilled migrants, has been less favourable. Ley and Kobayashi (2005), for example, note that while many skilled migrants from Hong Kong found it frustrating that they were underperforming economically in Canada, they preferred the country's outdoor quality of life compared to Hong Kong where business life generated higher financial returns. Ley's (2010) research on 'millionaire migrants' found that many affluent migrants from Hong Kong would move backwards and forwards as 'astronauts' (Ong, 1999) between Canada (for lifestyle purposes) and Hong Kong (for work purposes). The skilled migration literature suggests that Hong Kong holds an important positive reputational pull force for domestic and global talent, who are a looking for professional experience, opportunity and high salaries, but at the same time because of the high work demands on individuals, the city also has a strong negative reputational push force which has resulted in a highly skilled but transitory population. Here again, reputation plays an important role as a pull and as a push force in the mobility decisions of talented workers.

Countries such as China and India have recognised the important economic role of their diaspora in overseas countries. Saxenian (2006), for instance, has emphasised the major role that both countries have played in the success of the IT and engineering sector in the US. As a result, both countries have made active attempts to entice their diaspora to return to their home destination. Khadria (2002) has found that Indian professionals abroad have made a positive contribution to the Indian economy through start-up organisations and through filling highly skilled labour market shortages in high technology clusters such as Bangalore, by investing in government bonds and through participating in overseas diaspora events (Author, 2008). Certain regions of India such as Bangalore have built a very strong global reputation for IT and entrepreneurialism in large part because of the role of returning Indian migrants. These migrants have also contributed to India's 'brain bank' and have helped to build the country's reputation among foreign governments and companies as a producer of high quality talent as well as a place for potential future business and economic opportunities (Khadria, 2002). It is no coincidence, for example, that two of the top three countries that contribute to India's foreign direct investment (the US and the UK) are also the countries where large groups of skilled and affluent Indians reside (Ernst and Young, 2012).

China has also made active attempts to attract its overseas foreign talent to return through building the reputation of its business. In 2008, the national government introduced the 'Thousand Talent Program', which aimed to attract 2,000 Chinese IT experts and scholars as well as entrepreneurs who have been educated overseas. To date, 2,263 professionals have returned to 29 provinces and regions which represents an important contribution to the country's human capital (Zhang, 2012). Tung (2008) projects future problems though as many Chinese professionals moving abroad are not government sponsored and are not likely to return because, unlike government-funded professionals, there is no obligation to do so. Despite the fact that China has a large 
population of approximately 1.3 billion people (United Nations, 2012), it has a significant shortage of highly skilled talent: particularly professionals with managerial and cross-cultural management experience (Farrell and Grant, 2005). Although China, like India, has successfully attracted many of its own skilled workers abroad to return to the country, outside of Hong Kong, Shanghai and Beijing, it has been less successful at attracting other skilled migrant groups to the country. In large part this is because other cities in China have not built the same reputations as places to live and conduct business, both for global as well as for returning Chinese talent.

\section{Host and Home country: brain circulation}

Brain circulation is arguably a zero-sum game between the home and host country. Here, we are not referring to the first and second waves of skilled migration where there is the debate about whether countries have experienced a brain drain (first phase) or brain circulation (second phase). Instead, we are referring to where foreign talent returns to their home country and then subsequently invests in their former host country. A broader issue is that even if returning skilled migrants do not re-circulate to their host country, but make a positive impact by returning to their home country, then to what extent are they building the reputation of the host country as a place for world class tertiary education and professional training? Arguably, returning skilled migrants who do not invest in their host country can still play critical roles as 'reputationbuilders' for their host countries. The argument here is that through demonstrating their expertise and value abroad, this in turn can help to build the reputation of host countries as educators and developers of highly skilled talent. The Australian Government, for example, has recognised the high value of British talent in certain fields such as construction and engineering and targeted the UK as a source of talent through expos, job fares and recruitment events in London in order to fill skill shortages in Australia (DIAC, 2011a,b).

There is mounting evidence that home countries are benefiting from their talent abroad without them necessarily returning. In the Asia Pacific region, Saxenian (2006) found that Chinese, Indian and Taiwanese entrepreneurs have made a significant impact on their home countries, whilst still predominantly basing themselves in Silicon Valley in the US. To a large extent, this has been a result of the economic development and reputation building of these countries for business and entrepreneurial opportunities. The examples of South Korea and Taiwan demonstrate the significant shifts that both countries have experienced from brain drain towards brain circulation in light of their improved reputations (Song, 1997, 2003). Importantly, both countries have built their business reputations because they have attracted talent to these countries and enabled the development of their high-technology economies. Although microeconomic theories of migration suggest that individuals make a cost-benefit assessment of the strengths and weaknesses of transferring their skills for work purposes (Sjaastad, 1962; Borjas, 1999), there has been a tendency to emphasise economic factors over social factors. For instance, Author (2009) found that although professional opportunities and economic considerations are important for British and Indian scientists in the US when considering whether they would return to their home countries, family and friends, culture and lifestyle, social networks and to a lesser extent government incentives are also significant factors (see also Song, 2003). Despite the fact that social networks are an important determinant of whether professionals invested in and/or returned to their home country, these networks are frequently not harnessed (Author, 2009). In the context of China, Keren et al. (2003) found that social networks in China, whether they 
be professional, social, or family-oriented, have an important bearing on whether talented Chinese workers return. This is significant in the context of reputation because it is not only perceptions of economic and business conditions in a home country, but also social and network factors which may determine whether talented workers invest in and/or return to these countries.

Taiwan's answer to Silicon Valley has gained a reputation as a high technology centre in recent years with flow-on consequences. Indeed, the return of many highly skilled Taiwanese has coincided with the development and growth of the country's high technology industry, a success which has also been driven by those who have not returned. Saxenian (2006) rightly argues that many Taiwanese professionals shuttle back and forth between the US and Taiwan to start companies, build networks, consult and provide free advice. The origins of Taiwanese success stemmed from the large flow of Taiwanese students to the US in the 1970s and 1980s from prestigious universities in Taiwan who were 'pulled' by generous fellowship funding for graduate studies in the US and 'pushed' by a lack of professional opportunities in Taiwan (Saxenian and Hsu, 2001). This movement coincided with the major growth of technology in Silicon Valley and it is estimated that there were around 9,000 US-educated Taiwanese scientists and engineers in Silicon Valley in 2000. Importantly, because many Chinese immigrants felt socially and professionally isolated in the US, they formed associations such as the Chinese Institute of Engineers (CIE), which included a Taiwanese chapter, and Silicon Valley's Taiwanese American Industrial Technology Association (TAITA-SV). Such immigrant associations have acquired a reputation as being central to enabling migrants to build their careers in the US as well as to build and sustain global ties with their home country through government, private sector and university-led initiatives. These labour market intermediaries have been instrumental in building the reputation of Taiwan among global and domestic talent in Silicon Valley, which over time has contributed to brain circulation.

\section{Negative reputations}

This section focuses on host and home countries that have experienced negative reputations from talent staying (brain waste) or returning to and/or investing in another country (brain drain). We focus on brain waste from the host country and home country perspective before turning to examine brain drain from the host country and home country perspective.

\section{Host and Home country: brain waste}

Many educated immigrants in the US have faced significant difficulties with labour market performance, according to US Census data (Mattoo et al., 2008). Although skilled migrants from developing Asian countries performed better than skilled migrants from Latin America and Eastern Europe, there were still some concerning statistics for skilled migrants from the Asia Pacific. Of the skilled migrants who arrived in the US in the 1990 s, for example, only the following proportion of males with bachelor's degrees from their home countries held skilled jobs: 33\% from South Korea, 46\% from Taiwan, 40\% from the Philippines and 55\% from Vietnam (Özden, 2006, 238). Hence, the issue of brain waste among migrants from the Asia Pacific has been a major problem in the US, with the statistics likely to be significantly lower for skilled migrant women who frequently compromise on their careers for their male partners (Yeoh and Willis, 2005). The above statistics are significant because it appears that organisations within the US 
hold a particular bias towards certain migrant groups. It is critical to ensure that migrant skills are recognised, otherwise host countries run the risk of creating a reputation among potential talent as countries where they cannot work in areas commensurate with their education, training and skills.

Another significant finding from Mattoo et al. (2008) and Özden's (2006) research is that if other countries attract educated migrants through appealing migration policies then the average quality of migrants to the US as well as their likelihood of occupying a skilled job declines. In other words, there is a market for global talent and those countries which build a reputation for offering the best incentives will not only attract the best workers, but also affect the perceptions of mobility opportunities among potential talent in overseas countries. Finally, although brain waste is a problem for many skilled migrants at the point of arrival in a host country, there is less empirical evidence concerning the role of brain waste over time.

Like the Philippines, Indonesia is another Asia Pacific country which has exported a significant volume of its labour force. Although reliable statistics are not readily available, it is estimated that approximately 800,000 Indonesian citizens were working abroad in 2008 (Sukamdi, 2008). Having said this, the Indonesian government aims to stop sending its skilled workers abroad from 2017, according to the Manpower and Transmigration Minister, Muhaimin Iskandar (Jakarta Globe, 2012). The Minister qualified his statement by saying that this target may not be reached, not least because there may not be enough jobs in Indonesia. Hence, a challenge for Indonesia over the coming five years will be both opening-up opportunities for returning Indonesians and ensuring those opportunities are commensurate to their education, skills and training. According to the International Organisation for Migration (2010), there are a number of existing challenges for returning talent such as having to return to the address stated on their passport, which creates major logistical challenges if their family, friends and professional contacts have re-located to a different region, cutting them off from important social ties and therefore opportunities. In addition, there is very little assistance with insurance claims or with aid for those migrants wishing to start-up entrepreneurial or business ventures. In short, there is very limited infrastructure in place at present to support Indonesian returnees, which raises major questions about how the country will manage this process as increasing volumes of talent return with viable and useful skills and qualifications. This also raises the major issue of returning Indonesians finding work, let alone in an area equivalent to their prior training. Chain migration argues that people from the same home country will move to the same places through passing important migration information to one another through social networks (MacDonald and MacDonald, 1964). However, Indonesians abroad will arguably quickly hold negative perceptions of their home country if economic opportunities are not attractive for them to return, which will play the opposite role of chain migration and reduce talent mobility back to the country.

Thailand's Reverse Brain Drain (RBD) project has been an attempt by the national government to engage with Thai professionals living overseas in order to help the economic development of Thailand, particularly in the area of science and technology (Reverse Brain Drain Project, 2012). The programme was initiated in 1997 under the National Science and Technology Development Agency (NSTDA) in order to produce and disseminate new workforce planning knowledge for Thailand's needs. The logic behind this programme is that funding is dependent on: how innovative the project is; the extent to which it will aid and extend Thailand's competitiveness; and its commercial 
viability, including how it engages with Thai expertise abroad (ILO, 2009). To date, much of the partnerships have been with Thai universities or immigrant associations abroad. Wickramasekara (2002) cites the above initiative as a good example of promoting brain circulation, which is hard to dispute given the extensive list of positive past, present and future projects. However, Dahles (2009) cites a number of countries, including Thailand, which on the one hand have implemented initiatives for attracting talent, but then have little in the way of institutional support to retain talent. This is problematic because it means that although some returning talent benefit from economic opportunities, the majority find they do not fully utilize the training and skills acquired abroad, working in lower level positions in their home country. Naudé (2007) agrees that governments need to implement long-term strategies that will keep talent engaged as opposed to short term projects, which are very effective initially, but are likely to lead to brain waste in the long term because talent will either leave the country or remain in the country and work in areas not commensurate to their skills. The case of Thailand highlights an important programme which has catalysed the return of its talent through building the country's reputation for new business and economic opportunities, but it is questionable whether this programme has been successful at keeping these skilled workers engaged and maintaining a long term reputation for economic opportunities after the individual projects have been completed.

\section{Host country and Home country: brain drain}

One implication of the global war for talent is that it is a zero-sum game with winners and losers. While countries that attract and retain professionals stand to benefit from a surplus of human capital (brain gain), other countries that lose professionals suffer from a shortfall of human capital (brain drain). Saxenian (2006) is critical of the notion of the simplistic dualism of a brain drain versus a brain gain because many professionals need to leave their home countries in order to gain exposure to business, economic, social and cultural experiences in other regional economies. They also do not need to necessarily return to their home country at a later date in order to add value because they can invest and send remittances from the host country. This is arguably truer today than in the past because of major developments in technology, e-commerce and online networks which make it more straightforward and cheaper to send money electronically and conduct business virtually across international borders without having to permanently relocate to new markets (Straubhaar, 2000). It is important to consider the relative level of economic development between the home and host country because arguably a greater difference will increase the likelihood of talented professionals staying in the more developed host country, but at the same time make them more likely to invest in the less developed home country (Author, 2012a).

The Japanese government has made recent attempts to attract foreign talent, but has faced problems with employing foreign workers and retaining them. This is problematic because attracting and retaining talent is costly from both an economic and reputation perspective. The difficulty of attracting and retaining talent should be placed in historical context because until the 1980s Japan was a country of emigration with an immigration policy that prevented global talent from becoming permanent residents, which meant that it did not retain a lot of skilled migrants (Kamibayashi, 2006). In the last twenty years, the Japanese Government has actively encouraged skilled workers to move to Japan, which represents a major ideological shift. To illustrate, Japan has had a particular shortage of IT engineers, an estimate of 420,000 as identified by the Ministry of Internal Affairs and Communication (MIC). To address this shortage, the government 
has not imposed the usual quota system on incoming migrants provided they fulfill certain entry requirements. The country also included some mutual accreditation programs for IT engineers with eight other countries in the Asia Pacific (Kamibayashi, 2006). This is an attempt to reduce the problem of brain waste by ensuring that the skills of global talent working in Japan are recognised. Despite active attempts to recruit global talent in IT engineering, firms in Japan have experienced major difficulties with retention because of communication problems. Kamibayashi $(2006,183-184)$ argues that it is not merely understanding the Japanese language which is problematic, but also understanding the subtleties and nuances. She provides the example of 'I will think it over' as often meaning 'I won't accept your proposal' in Japanese business. In short, many skilled foreign workers find it hard to integrate into professional and social life in Japan, which has created a lot of problems in terms of retention. At the same time, Japan has also faced a negative reputation among its young skilled domestic workers who feel that they are confronted with generational glass ceilings in the labour market where older generations are not providing many young, ambitious and entrepreneurial workers with opportunities for career mobility within organisations, and more broadly within the labour market (Fackler, 2011). In this respect, Japan's reputation is perceived negatively by two groups of talented workers (global and domestic talent), both of whom are contributing to the country's brain drain at a time when Japan needs talent to boost productivity in an increasingly ageing workplace which is suffering from what was touted in 2011 as a triple crisis (Kaufmann and Penciakova, 2011).

There are a number of examples of where the brain drain exists within and beyond the Asia Pacific region (Hugo et al., 2013). Bernama, the official government news agency of Malaysia, for example, cited that the country has over one million talented Malaysians working overseas, both in Asia Pacific countries such as Singapore and Australia, as well as in countries outside of the region such as the US and the UK. What is particularly troubling for Malaysia is that the brain drain appears to have accelerated, with 140,000 talented people leaving the country permanently in 2007 compared to 305,000 between March 2008 and August 2009 (Asia Sentinel, 2010). This is concerning because high volumes of talent leaving a country sends negative reputational signals to existing talent in the country, exacerbating the brain drain; as well as to potential talent abroad, potentially reducing the inflow of foreign talent.

While the brain drain is seen to be a linear process of exit by skilled workers to better opportunities, there are some myths about the brain drain. New Zealand, for example, is commonly cited as suffering a brain drain to Australia, but Statistics New Zealand (2012) argue that although the country does lose skilled professionals, overall it gains more skilled workers than it loses because those that arrive tend to come with more skills than those who depart. This is an important point to emphasise because all countries in the Asia Pacific will experience different levels of brain gain, brain circulation, brain waste and brain drain, which will influence and be influenced by different reputations. However, as we have highlighted with the typology above, countries in the Asia Pacific experience markedly different relative inflows and outflows of talent as a result of their disparate reputations. Malpass (2012) argues that the crossTasman brain drain is in decline and the general pessimism among New Zealanders about their talent being lost to Australia is misplaced. He argues that the pendulum is slowly swinging in favour of New Zealand over Australia. This shows that common stereotypes about a brain drain, which become popular national debates, can often be led by rumour rather than reality. This is reinforced because many sending countries as 
well as organisations hold poor data on the loss of talent (Lowell and Findlay, 2002; KPMG, 2011).

\section{Conclusions}

This paper has argued that reputation plays a central role in the mobility of talent. We have argued that different forms of reputation in the host and home country affect the attraction and retention of talented workers. We have also shown that individual talent is not only influenced by but produces reputation based on their direct experiences, which shapes their own perceptions as well as those of other talented workers. This is an important contribution to the reputation and talent mobility literature where the emphasis has been largely on organisations and domestic talent (Chambers et al., 1998; Michaels et al., 2001; Fombrun, 1996, 2012).

\section{Insert Figure 1 about here}

As Figure 1 highlights, the mobility of talent is determined by the positive and negative reputations that these skilled workers hold towards host and home countries. This is an important contribution because the activities of governments shape the perceptions that potential, existing and former talented workers hold towards particular places. This in turn determines whether they move in the first instance, and, based on their personal experiences, stay or return in the second instance, which over time determines whether the host and home countries experiences a net gain or a net loss of talent. This is critical because such outcomes have major political, economic and social ramifications for countries and organisations, yet to date, the role of reputation has been almost entirely absent in explanations of talent mobility.

We have presented a typology of reputation and talent mobility, drawing upon a crosssection of examples within the Asia Pacific. We have shown that home and host countries in the Asia Pacific experience brain gain, brain circulation, brain waste and brain drain, and the idea of a brain gain versus a brain waste, and a brain drain versus brain circulation is problematic and overly simplistic in the context of this region. This is critical to highlight because the skilled migration literature has often treated the above as binary processes, but as Saxenian (2006) rightly highlights it is possible for countries to experience different categories, such as gains and losses, simultaneously. We argue that talented workers can contribute positively to both host and home countries. With host countries, they can act as important 'reputation builders' for their governments and help to build transnational social networks as well as a positive reputation for their home countries and employers. With home countries, they can provide positive economic, political and social returns from their educational and professional experience abroad, which can help to promote innovation and economic development in their home country. In the process, they can also help to build the reputation of the host country as a place of excellence in education and professional development. In short, talent can act as reputation builders for both home and host countries. Of course, they can also be 'reputation damagers', which is particularly likely if their past experiences have been negative.

\section{Implications for management}

This paper holds important lessons for different institutions seeking to attract and retain talent. First, positive reputations catalyse the mobility of talented workers to particular places. Hence, countries that offer enticing economic, political and social 
incentives send a strong signal to the global labour market that they are open for business and to a variety of types of talented workers. Second, attracting talent is only one of the battles in the war for talent, and this is particularly true today as workers are increasingly mobile. As a result, national governments need to ensure that the talented workers that they have successfully attracted are satisfied in their jobs and communities. This means proactively working with organisations, industry bodies, professional associations, immigrant associations, local government and other relevant interest groups to ensure that these workers are employed in areas equivalent to their education, training and skills, and are successfully integrated into local communities. In short, national governments who work with other relevant stakeholders and that offer genuine opportunities for talented workers to both migrate and integrate will fare significantly better in the global war for talent than governments that offer only limited incentives and services. Finally, there has been a tendency to assume that talented workers are passive actors. However, these individuals are often highly strategic in their migration and investment decisions. Hence, governments and organisations would be advised to treat talented workers as important assets not merely for satisfying skill gaps but also for attracting and retaining future talent, for attracting foreign direct investment and for helping to advocate a country's openness to welcoming global and returning talent.

\section{Future research}

Although this paper has focused on the perspective of host and home countries, it is important to recognise the role of other actors such as organisations and talented workers which we have touched on very briefly. Governments, for example, are looking to achieve national economic growth and competitiveness, fill labour market shortages as well as satisfy the needs of their electorate. Organisations, on the other hand, aim to gain a competitive advantage over other organisations, attract and retain the highest quality workers to fill workplace shortages and to reduce their costs in the process and to meet the need of their primary stakeholders. It is also critical to consider that the perspective of governments and organisations do not always map onto those of talented professionals, whose preferences vary across geographic space and over time (Author, 2011a,b). This is important theoretically because the different priorities of governments and organisations shape their policies towards attracting and retaining talent, but this does not necessarily align with what drives talented workers to move or stay. A fruitful area for future research would be an examination of how and why the needs of these different groups converge or diverge across geographic space and over different time periods. Furthermore, breaking this down to examine the experience of talented men and women would also be valuable. It is also important for us to ask how can both governments and organisations most effectively benefit from talented workers as well as utilise them to build their reputations, whilst at the same time ensuring that they are satisfying their social and professional needs? To date, these actors have tended to be treated in isolation and an important area for future research would be to examine their interaction with each other as well as with new forms of intermediaries who shape both reputations and mobility choices (Authors, 2014).

Further research could also explore what drives certain groups to want to invest, return and contribute to the economic development of their home countries versus other groups who are more reticent. Equally, we have shown that several governments have started initiatives to attract their talent to return, but it is not clear whether these programs have been successful in the long term. In short, additional research is needed 
on the transitory and global nature of talent mobility as well as on the multiplicity of government, organisational and institutional actors who are building and damaging various reputations over short and long term time periods. We would suggest that multiple forms of reputation building, including using talent as ambassadors in this process, would represent an important first manoeuvre for national governments.

\section{References}

Adam S (2013) Singapore Protest Exposes Voter Worries About Immigration.

Bloomberg. Url: http://www.bloomberg.com/news/2013-02-16/singaporeans-protestplan-to-increase-population-by-immigration.html

AFR [Australian Financial Review] (2012) 'Reputation, agility and talent are tops' Boss Financial Review, 17, 34.

Al Ariss A and Syed J (2011) Capital mobilization of skilled migrants: a relational perspective. British Journal of Management, 22(2), 286-304.

Asia Sentinel (2010) Malaysia's Brain Drain. Url:

http://www.asiasentinel.com/index.php?option=com_content\&task=view\&id=2308\&It emid=199

Author (2008)

Author (2009)

Author (2011a)

Author (2011b)

Author (2012a)

Author (2012b)

Authors (2012)

Authors (2013)

Author (2013)

Baldwin-Edwards M (2005) Migration in the Middle East and Mediterranean, Mediterranean Migration Observatory, Greece.

Beaverstock JV (2002) Transnational elites in global cities: British expatriates in Singapore's financial district. Geoforum, 33(4), 525-538.

Borjas GJ (1999) The economic analysis of immigration. Handbook of Labor Economics, 3(Part 1), 1697-1760.

Kaufmann D and Penciakova V (2011) Japan's Triple Disaster: Governance and the Earthquake, Tsunami and Nuclear Crises. Url:

http://www.brookings.edu/research/opinions/2011/03/16-japan-disaster-kaufmann\#

Campbell EK (2001) Preferences for emigration among skilled citizens in Botswana.

International Journal of Population Geography, 7(3), 151-171.

Chambers EG, M Foulon, H Handfield-Jones, SM Hankin and EG Michaels, (1998) The war for talent, McKinsey Quarterly, 1(3), 44-57.

Cooke FL (2011) Talent management in China. In H Scullion and DG Collings (eds) Global Talent Management, 132-154. Routledge, New York and Abingdon, VA. 
Cooke, FL (2012) Human resource management in China: New trends and practices, London: Routledge.

Collings DG and K Mellahi (2009) Strategic talent management: A review and research agenda. Human Resource Management Review 19(4), 304-313.

Dahles H (2007) Return Migration as an Engine of Social Change? Reverse Diasporas' Capital Investments at Home: a Comparative Perspective. $2^{\text {nd }}$ Global Conference DIASPORAS - Exploring Critical Issues Mansfield College, Oxford, July 6-9, 2009. Url: http://www.inter-disciplinary.net/wpcontent/uploads/2009/06/diasporasdahlespaperfinal.pdf

Derudder B, P Taylor, P Ni, A De Vos, M Hoyler, H Hanssens, and X Yang (2010) Pathways of Change: Shifting Connectivities in the World City Network, 2000-08. Urban Studies, 47(9), 1861-1877.

DIAC [Department of Immigration and Citizenship] (2011a) Visas, Immigration and Refugees. http://www.immi.gov.au/skillexpos/2011-info-feedback.htm

DIAC [Department of Immigration and Citizenship] (2011b) Visas, Immigration and Refugees. http://www.immi.gov.au/skillexpos/skilled-workers.htm

DIAC [Department of Immigration and Citizenship] (2012) Consolidated Sponsored Occupation List (CSOL). Schedule 1 and Schedule 2. Url:

http://www.immi.gov.au/skilled/_pdf/sol-schedule1-2.pdf

(The) Economist (2006) The battle for brainpower Url: http://www.economist.com/node/7961894

Employer Branding Today (2011) How does the reputation of a country affect its ability to attract talent from abroad? Url:

http://www.employerbrandingtoday.com/blog/2011/01/20/country-image-problemsdisturb-global-talent-attraction/

Ernst and Young (2012) Ready for the transition. Ernst \& Young's 2012 attractiveness survey. India. Url:

http://www.ey.com/Publication/vwLUAssetsPI/Indian_Attractiveness_Survey_2012/\$F ILE/Ernst\%20\&\%20Young\%202012\%20India\%20attractiveness\%20survey.pdf

Fackler M (2011) The Great Deflation. In Japan, Young Face Generational Roadblocks. The New York Times. Url:

http://www.nytimes.com/2011/01/28/world/asia/28generation.html?pagewanted=al 1

Farrell D and AJ Grant (2005) China's Looming Talent Shortage. McKinsey Quarterly, 4, 70-79.

Findlay AM, FLN Li, AJ Jowett and R Skeldon (1996) Skilled International Migration and the Global City: A Study of Expatriates in Hong Kong. Transactions of the Institute of British Geographers, 21(1), 49-61.

Fombrun C J (1996) Reputation. Realizing Value from the Corporate Image. Boston, Massachusetts: Harvard Business School Press.

Fombrun CJ (2012) The building blocks of corporate reputation: definitions, antecedents, consequences. In The Oxford Handbook of Corporate Reputation (Eds. Barnett ML and TG Pollock), 94-113. 
Florida R (2005) The Flight of the Creative Class. New York: Harper Business.

Graves C (2010) Designing a distinctive national brand. In South Korea: Finding its place on the world stage. McKinsey \& Company Insights and Publications. Url:

http://www.mckinsey.com/insights/winning_in_emerging_markets/south_korea_findin g_its_place_on_the_world_stage

Grubel HB and AD Scott (1966) The international flow of human capital. American Economic Review 56(1/2), 268-274.

Ho ELE (2011) 'Claiming' the diaspora: Elite mobility, sending state strategies and the spatialities of citizenship. Progress in Human Geography, 35(6), 757-772.

Hugo G (2013) Migration and Development in Asia and a Role for Australia, Journal of Intercultural Studies, 34(2), 141-159

Hydrogen (2013) Singapore acts to stop the brain drain. Url:

http://www.hydrogengroup.com/Singapore_acts_to_stop_the_brain_drain

ILO [International Labour Organization] (2009) The Reverse Brain Drain Project, Thailand. Url:

http://www.ilo.org/dyn/migpractice/migmain.showPractice?p_lang=en\&p_practice_id= $\underline{43}$

ILO [International Labour Organization] (2013) Global unemployment rising again but with significant differences across regions. Url: http://www.ilo.org/global/about-theilo/newsroom/news/WCMS_202320/lang--nl/index.htm

IOM [International Organization for Migration] (2010) Labour migration from Indonesia. An overview of Indonesian migration to selected destinations in Asia and the Middle East. Jakarta, Indonesia: IOM.

Jakarta Globe (2012) Indonesia Plans to Stop Sending Domestic Workers Abroad by 2017. Url: http://www.thejakartaglobe.com/home/indonesia-plans-to-stop-sendingdomestic-workers-abroad-by-2017/489148

Jones JT, M Whitaker, P-S Seet, and J Parkin (2012) Talent management in practice in Australia: individualistic or strategic? An exploratory study. Asia Pacific Journal of Human Resources, 50(4), 399-420

Kamibayashi C (2006) Current migration of IT engineers to Japan: Beyond immigration control and cultural barriers. In Kuptsch, C and Pang, EF (eds.) Competing for Global Talent. Geneva: International Institute for Labour Studies, International Labour Office, 171-185.

Keren L, F Guo, and H Ping (2003) China: government policies and emerging trends of reversal of the brain drain. In Return Migration in the Asia Pacific. Iredale R, F Guo and S Rozario (eds) Cheltenham: Edward Elgar, 88-111.

Khadria B (2002) Skilled Labour Migration from Developing Countries: Study on India. International Migration Papers No. 49, Geneva: International Labour Office.

Kim Y-H and JA Lee (2012) To Outdo Rivals in Mobile Software, Samsung Turns to Outside Talent. Wall Street Journal. Url:

http://online.wsj.com/article/SB10001424052702303877604577381601758850814.h tml 
Koh A (2003) Global flows of foreign talent: identity anxieties in Singapore's ethnoscape. Journal of Social Issues in Southeast Asia, 18(2), 230-256.

KPMG (2011) Global Assignment Policies and Practices, Survey 2011, Global Mobility Advisory Services, KPMG International.

Ley D and A Kobayashi (2005) Back to Hong Kong: Return migration or transnational sojourn? Global Networks, 5(2), 111-127.

Ley D (2010) Millionaire Migrants: Trans-Pacific Life Lines. Chichester: Blackwell-Wiley.

Lowell BL and AM Findlay (2002) Migration of Highly Skilled Persons from Developing Countries: Impact and Policy Responses - Synthesis Report. International Migration Papers No. 44. Geneva: International Labour Office.

MacDonald JS and LD MacDonald (1964) Chain migration ethnic neighborhood formation and social networks, The Milbank Memorial Fund Quarterly, 42(1), 82-97.

Mahroum S (1999) Skilled Labour (Competing for the Highly Skilled: Europe in Perspective). Science and Public Policy, 26, 17-25.

Malpass L (2012) NZ brain drain in decline. Australian Financial Review. Url: http://afr.com/p/opinion/nz_brain_drain_in_decline_CD8wLGzqb1GzLVHZq2Kp2I

Mattoo A, JC Neagu and C Özden (2008) Brain waste? Educated immigrants in the US labor market, Journal of Development Economics, 87(2), 255-269.

McDonnell A, P Stanton and J Burgess (2011) Multinational enterprises in Australia: Two decades of international human resource management research reviewed. Asia Pacific Journal of Human Resources 49(1), 9-35.

McDonnell A, DG Collings and J Burgess (2012) Guest editors' note: Talent management in the Asia Pacific. Asia Pacific Journal of Human Resources, 50, 391-398.

Michaels E, H Handfield-Jones and B Axelrod (2001) The War for Talent. Boston: Harvard Business School Press.

Nakamuro M and K Ogawa (2010) Mobility of Skilled Labor in Transition Economies: The Perspectives from Brain-Drain, Brain-Waste, Brain-Circulation and Brain-Gain. Journal of International Cooperative Studies, 18(1), 71-84.

Naudé W (2007) Peace, Prosperity, and Pro-Growth Entrepreneurship, United Nations University-WIDER, Discussion paper no. 2007/02. Url:

http://www.wider.unu.edu/publications/working-papers/discussionpapers/2007/en_GB/dp2007-02/_files/78114309114626984/default/dp2007-02.pdf

Ng PT (2011) Singapore's response to the global war for talent: Politics and education. International Journal of Educational Development, 31(3), 262-268.

OECD (2002) Student mobility between and towards OECD countries: a comparative analysis. Trends in International Migration: SOPEMI 2001. Paris: OECD: 93-117.

Ong A (2007) Please stay: Pied-a-Terre subjects in the megacity, Citizenship Studies, 11(1), 83-93.

Özden C (2006) Educated Migrants: Is there brain waste? In Özden, C. and Schiff, M. (eds.). International Migration, Remittances, and the Brain Drain. Washington, D.C.: World Bank, 227-244. 
Reverse Brain Drain Project (2012) About RBD. Url:

http://rbd.nstda.or.th/rbdweb/about_rbd/index.php

Robertson A and G Abbey (2003) Managing Talented People: Getting on with-and Getting the Best from-Your Top Talent. Momentum Wcze.

Royal Society (1963) Emigration of Scientists from the United Kingdom. London: Royal Society.

Saxenian A and J-Y Tsu (2001) The Silicon Valley-Tsinchu Connection: Technical Communities and Industrial Upgrading. Industrial and Corporate Change, 10(4), 894920.

Saxenian A (2005) From brain drain to brain circulation: Transnational communities and regional upgrading in India and China. Studies in Comparative International Development, 40(2), 35-61.

Saxenian A (2006) The New Argonauts: Regional Advantage in a Global Economy. Harvard University Press, Cambridge, MA.

Sjaastad LA (1962) The costs and returns of human migration. Journal of Political Economy, 70(5), 80-93.

Song H (1997) From Brain Drain to Reverse Brain Drain: Three Decades of Korean Experience. Science Technology \& Society, 2(2), 317-345.

Song H (2003) Networking Lessons from Taiwan and South Korea. United Nations Public Administration Network (UNPAC). Url:

http://unpan1.un.org/intradoc/groups/public/documents/apcity/unpan022359.pdf

Stark O, C Helmenstein and A Prskawetz (1997) A brain gain with a brain drain. Economics Letters, 55(2), 227-234.

Statistics New Zealand (2012) New Zealand is losing more skilled and educated people than we're gaining in the 'brain drain.' Url:

http://www.stats.govt.nz/browse_for_stats/population/mythbusters/brain-drain.aspx

Straubhaar T (2000) International mobility of the highly skilled: brain gain, brain drain or brain exchange, Hamburg: Hamburg Institute of International Economics, Discussion paper 88.

Sukamdi (2008) Indonesia. Asian and Pacific Migration Journal, 17(3-4), 325-334.

Suutari V and C Brewster (2000) Making their own way: international experience through self-initiated foreign assignments. Journal of World Business, 35(4), 417-436.

Tarique I and RS Schuler (2010) Global talent management: Literature review, integrative framework, and suggestions for further research. Journal of World Business, 45(2), 122-133.

(The) Temasek Times (2012) PM Lee: We must continue to attract 'foreign talents' to come to Singapore. Url: http://temasektimes.wordpress.com/2012/07/11/pm-lee-wemust-continue-to-attract-foreign-talents-to-come-to-singapore/

Tharenou P, and N Caulfield (2010) Will I stay or will I go? Explaining repatriation by selfinitiated expatriates. Academy of Management Journal, 53(5), 1009-1028.

Tung, RL (1988) The New Expatriates: Managing Human Resources Abroad. Cambridge, MA: Ballinger Publisher. 
Tung RL and M Lazarova (2006) Brain drain versus brain gain: an exploratory study of ex-host country nationals in Central and East Europe, The International Journal of Human Resource Management, 17(11), 1853-1872

Tung RL (2008) Brain circulation, diaspora, and international competitiveness. European Management Journal, 26(5), 298-304.

United Nations (2012) UN data. A world of information. China: World Statistics Pocketbook. United Nations Statistics Division, http://data.un.org/CountryProfile.aspx?crName=CHINA

Yeoh BSA and K Willis (2005) Singaporeans in China: transnational women elites and the negotiation of gendered identities. Geoforum, 36(2), 211-222.

Wade, JB, Porac, JF, Pollock, TG, and SD Graffin (2006) The burden of celebrity: the impact of CEO certification contests on CEO pay and performance. Academy of Management Journal, 49(4), 643-660.

Walker K (2010) A systematic review of the corporate reputation literature: Definition, measurement, and theory. Corporate Reputation Review, 12(4), 357-387.

Wickramasekara P (2003) Policy Responses to Skilled Migration: Retention, Return and Circulation. Perspectives on Labour Migration, 5E. Geneva: International Labour Office.

Wright CF (2013) How Do States Implement Liberal Immigration Policies? Control Signals and Skilled Immigration Reform in Australia. Governance.

Zhang Y (2012) Thousand Talent Program brings more pros, http://www.chinadaily.com.cn/bizchina/2012-04/28/content_15168335.htm 


\section{Figure 1: A typology of reputation and talent mobility}

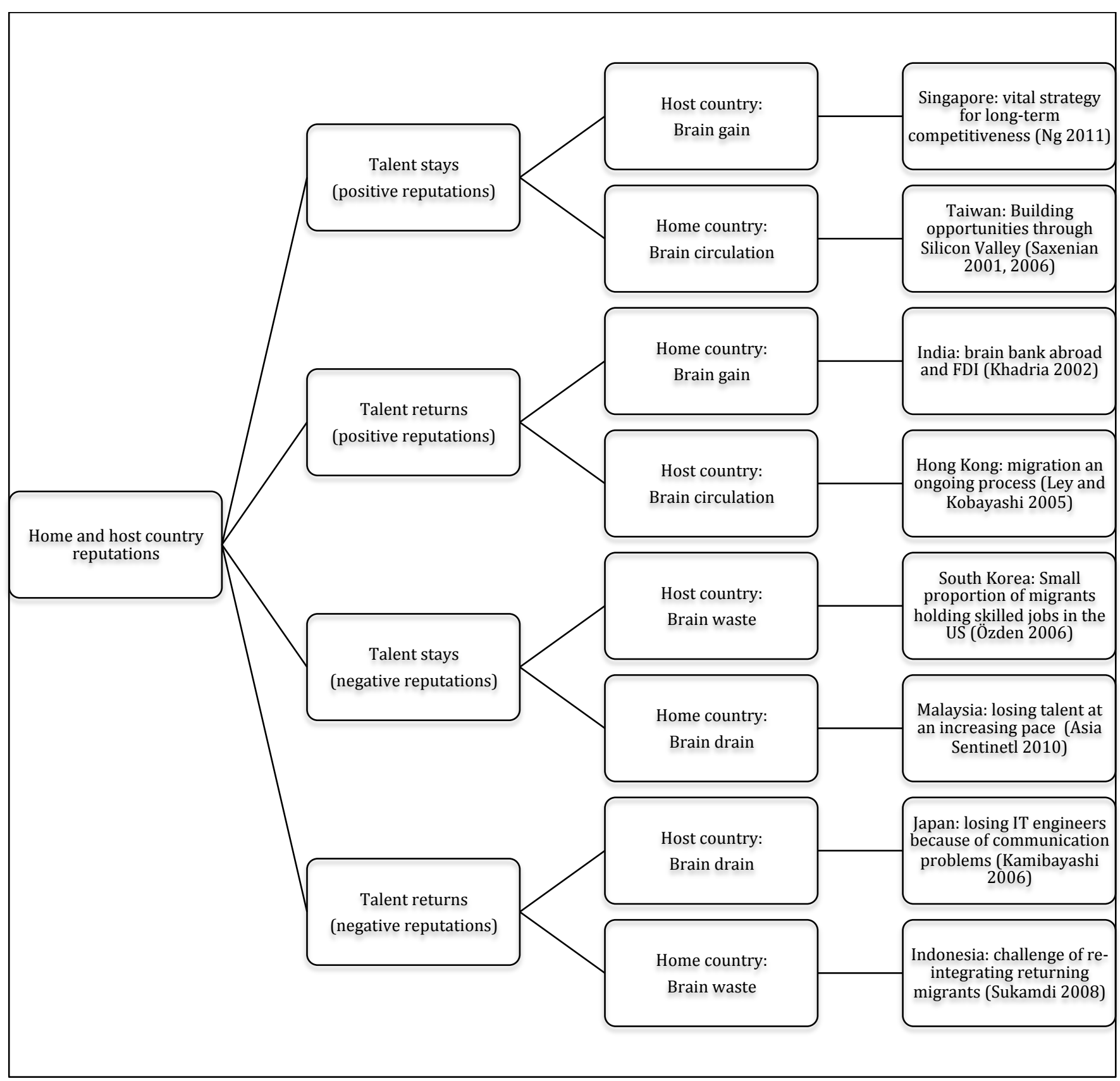

